\title{
Kuchnia w tradycji dnia powszedniego i świąt karaimskich
}

\author{
ZOFIA ABKOWICZ
}

Michaił S. Saracz, osiadły we Francji uchodźca porewolucyjny z Krymu, w swych wspomnieniach o kulturalnym życiu Paryża lat międzywojennych, wspominał: „rosyjskie bale sławne były z głosów i urody swych śpiewaczek, gruzińskie z tańca - lezginki, a karaimskie wsławiły się swoją kuchnią". Kuchnia była i pozostaje jednym z najważniejszych elementów życia społecznego karaimów i nośnikiem ich kultury. Każda gospodyni przyjmując gości, przede wszystkim dba o to, by nie byli głodni, by zostali nakarmieni. Przysmaki kuchni karaimskiej opiewali poeci. Szymon Firkowicz z Trok pisał tak:

Kybyn i kluski

W karaimskim starym domu kybyn z kluskami w rosole pokłóciły się w piątek,

Kto pierwszy pojawił się na stole.

Kybyn z dziureczkami w brzuchu, Kompanami otoczony Zaraz zaszczebiotał słodko , Swą tłustością ośmielony:

„Przy księżycu zawitałem do królestwa naszych pań, I zostałem na wsze czasy jako najważniejsze z dań.

Gdy Karaim mnie zobaczy, Gdy poczuje moja woń Nie zważając na gorąco , Chwyta zaraz w swoją dłoń
Kybyn da tutmacz

Bir kart kierti karaj űwdia Kybyn tutmaczba tałaszty. (Ki bu edi baraskidia, Adiet' bizgia syrny aczty).

Kajnar dostłar arasynda Siemiz, tołu kybynczechnym, Teszicz'eklarbia karnynda Ijdi cziebiar awazczehyn.

„Aj tabułmach wachttan eńdim

Bijik kioktiań karajłarha

Da barcze ałarha edim

Enk burunhu bar aszłarha.

Kiorsia mieni Karaj uwłu, Sielagiasi ahat fordan.

Kuczat mieni tanysz kołu, Bisziklaniadir szorbamdan. 
Pod krupniczek czy wódeczkę

- ja się także napić lubię -

Z masełkiem i ogóreczkiem,

Dać się przekąsić nie odmówię!

A gdy schowam się w żołądkach obżartuchów chciwych jadła, posłucham jeszcze piosenki, co się wydobywa z gardła.

Słuchać dłużej już nie mogąc tych kybynowych przechwałek, Makaron ze złości cały spęczniał, Wyjrzał z rosołu gruby jak wałek

Wąsy swoje długie, tłuste za brzeg talerza wystawił, i rozpoczął swą opowieść

- teraz on się będzie chwalił!

„Ród mój stary, znakomity, Ojciec - placek, dziad - zacierka, Moje ciasto wałkowane, Żadna tam wymięta ścierka!

Dobrze znam się z Karaimem, Ze mną wita on swe święta, W czym ja gorszy od kybyna, Tego... tego... parzyręka!

Gdy chcę, z łyżki zaraz zwisnę, Nawet tej jak chochla dużej, Wokół bezzębnych ust Za wąs i brodę posłużę.

Żółty, miękki, smakowity, z jajek czerpię siłę swoją. W domu skąpca blednę, rzednę, Boże, ratuj duszę moją!

Zjadł Karaim rosół z kluskami, Zagryzł kybynem raz dwa, W brzuchu już się pogodziły I do dziś ich przyjaźń trwa.
Son krupniczek hiem czahyrczech

Kujadyr kiopmia iczals'am, Saryjawczech da chyjarczech Aszejmyn kiopmia jenialsiam.

Da astranyp opchachlardan Issi awłach karynczechka, Tujam szatyr jirczechlardan Joch ucz mieni machtamachka."

Bołałmady tutmacz artych Tujma kybyn machtanmahyn, Biorttiu, ałdy any achłych, Asztan sundu ajaczehnyn.

Mieńdi tiepsi kyryjyna, Tachty uzuń mijychłaryn Da baszłady jołdaszyna Tiokmia ügiut' ajtmachłaryn:

„Czyham eśki mień uruvdan, Atam - umacz, ittam - jajmacz. Siemiź baschan mień chamurdan Da avałdan adym - tutmacz.

Jachszy tanysz mień karajha, Chydżny kieliam utrułama, Tieńszy tiuwiul' mień kybynha, Bołałmyt koł mieni ałma.

Klasiam, ułłu-de kaszuchtan Taham uzun ajahymny, Klasiam, tiszsiź awuzczochtan Salam janha mijyhymny.

Jumyrtczechba kiplańsiam, Sary bolam da tatuwłu. Kyzhancz kołha mień ilińsiam, Tejź aharym, Tieńri jułu!"

Da esztip bu tałaszny, Ałdy karaj kybynczechny Tutmaczba awzunda koszma, Ki karynda bazłasztyrma. 
Podstawą tradycyjnej kuchni polskich Karaimów są uprawiane w domowych ogródkach warzywa i nabiał, przy okazjach specjalnych wzbogacane mięsem: drobiem, baraniną, koźlęciną i wołowiną. Wykorzystuje się też ryby słodkowodne i morskie. Z warzyw poczesne miejsce zajmują ziemniaki, kapusta, marchew, cebula, buraki, brukiew. Mięso, ryby, ziemniaki, ryż lub kapusta występują często $\mathrm{w}$ połączeniu $\mathrm{z}$ popularnym słonym ciastem drożdżowym. Ciasto to występuje również w wersji słodkiej, służąc do przygotowywania deserów i ważnych w tradycji wielu świąt wypieków - bułek drożdżowych o różnych kształtach. Cechą charakterystyczną kuchni karaimskiej jest występowanie dań w dwóch wersjach: postnej, podawanej w dni postu i przy żałobnych okazjach oraz $\mathrm{w}$ wersji niepostnej, przeznaczonej na okazje radosne. Wszelkie ważne momenty i wydarzenia zarówno w życiu osobistym, jak i społecznym Karaimów akcentowane są właściwą tradycją kulinarną. Niestety, w dobie fast-foodów i ciągłego pośpiechu, tradycja ta powoli znika, dlatego też postanowiliśmy ocalić od zapomnienia specjały tej kuchni. Prezentujemy je ujęte w ramy kalendarium świąt i dni uroczystych. Na początek jednak kilka informacji i przepisy na ciasta - podstawę wielu dań tradycyjnej kuchni karaimskiej.

\section{Ciasta podstawowe}

Ciasto makaronowe

Składniki: 1 jajko, 0,5 szklanki wody, 0,25 kg mąki, sól.

Wyrabia się z niego:

Tutmacz (makaron) - wałkowane ciasto krojone na paski szerokości jednego centymetra, używane do przygotowania zapiekanek na słodko i pikantnych oraz farszu do pieczonego mięsa.

Umacz (zacierki z twardego ciasta z wody i mąki) - świeże ciasto ścierane na tarce buraczanej lub odrywane ręką - podawane w dni powszednie.

Szczypanka (na zdjęciu) - formowane z ciasta cienkie wałeczki, krojone następnie na kawałeczki jak kopytka i pieczone w piekarniku. Tak przygotowane wrzuca się do gorącego rosołu.

\section{Ciasto drożdżowe}

\section{Słodkie - na ozdobne wypieki}

Składniki: 1 kg mąki, 1-2 jajka + 1-2 żółtka, szczypta soli, 0,5 kostki margaryny, 2-3 łyżki stołowe oliwy, 0,25 kostki masła (lub tylko 1 kostka masła), $10 \mathrm{dkg}$ drożdży, ok. pół litra mleka;

\section{Ciasto na bułeczki:}

Składniki: 1 kg mąki, 1 jajko i/lub 1 żółtko, 1 szkl. cukru, szczypta soli, 10 dkg masła lub margaryny, 1-2 łyżki stołowe oliwy, 2-5 dkg drożdży, 2 łyżki mleka;

Ciasto na wypieki postne:

Składniki: 1 kg mąki, 1 jajo, 100 g margaryny, trochę oleju i masła, 3 dkg drożdży, mleko. 
Sposób przygotowania: Podgrzać lekko mleko. Do naczynia włożyć drożdże, parę łyżek cukru i zalać 2-3 łyżkami ciepłego mleka. Rozetrzeć. Nasypać trochę mąki i zostawić do wyrośnięcia. Rozpuścić margarynę i część masła. Umyć jajka, jedno jajko i jedno żółtko rozetrzeć z cukrem do białości. Do miski przesiać część mąki (2/3), wyłożyć podrośnięte drożdże, kogel-mogel, mleko. Zagniatać ciasto, dodając stopniowo resztę mąki i mleka. Wyrabiać aż powstanie masa o właściwej konsystencji - powinna być miękka i sprężysta. Następnie dodawać stopniowo tłuszcz, wgniatając go powoli w ciasto - im dłużej ciasto wyrabiane, tym lepsze. Na sam koniec wyłożyć resztę tłuszczu na ręce i wmiesić. Ciasto powinno mieć jednolitą konsystencję, nie może kleić się do rąk. Ciasto obsypać mąką i przykryć ściereczką. Postawić w cieple do wyrośnięcia na mniej więcej pół godziny. Gdy urośnie, formować wypieki. Przed wstawieniem do piekarnika smarować wyrób rozbełtanym jajkiem ze szczyptą soli lub cukru.

\section{Szczególne dni w tygodniu}

\section{Piątek}

Piątek w domu karaimskim był dniem szczególnym, w którym przygotowywano cały dom do cotygodniowego święta - soboty. Wszystkie kobiety w domu dzieliły czas pomiędzy sprzątaniem i przygotowywaniem posiłków na dwa dni: piątek i sobotę. Potrawy piątkowe nierzadko były zapowiedzią sobotniego menu. Mogły to być:

Kybyny - pieczone w piecu pierogi, najsłynniejsze danie kuchni karaimskiej.

Ciasto drożdżowe słone.

Farsz: 3/4 kg mięsa baraniego lub wołowego (tłustego) i $1 / 4 \mathrm{~kg}$ kapusty.

Surowe mięso kroimy w kosteczkę (nie mielimy!), siekamy (szatkujemy) kapustę, dodajemy pokrojone w kosteczkę 2-3 cebule, sól , pieprz. Podlewamy wodą, tak by farsz był soczysty.

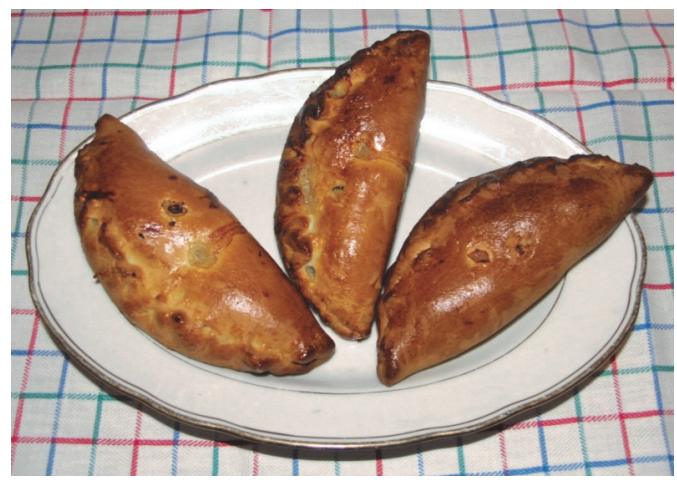

Ciasto dzielimy na bułeczki o średnicy ok. $5 \mathrm{~cm}$. Rozwałkujemy je na okrągłe placki wielkości dłoni. Na połowę placka nakładamy farsz. Sklejamy zewnętrzne krawędzie formując pierog i tworząc charakterystyczny „warkoczyk" na brzegu. Przed włożeniem do pieca szczypiemy palcami kybyn pośrodku, by zrobić dziurki (nazwa kybyn pochodzi od słowa kypma - szczypać) i smarujemy rozbełtanym jajkiem. Kybyny układamy na blasze wysmarowanej tłuszczem i pieczemy w średnio nagrzanym piekarniku aż nabiorą złotego koloru.

Blin - niska babka, placek kartoflany pieczony w brytfannie, z tartych ziemniaków z mięsem lub bez, w postne dni z poszatkowaną kapustą. 
Kyjma - kiszki wołowe faszerowane tartymi ziemniakami z drobno pokrojonym mięsem i cebulą, pieczone w piekarniku.

\section{Desery:}

Kaszniki - pierożki ze słodkiego ciasta drożdżowego z serowym farszem. Twaróg, jajka, cukier i odrobinę masła zmiksować, następnie dodać rodzynki i pokrojoną skórkę pomarańczową. Ciasto podzielić na bułeczki, każdą rozwałkować, nałożyć farsz, zawinąć zewnętrzne brzegi formując tradycyjną formę, posmarować rozmącanym żółtkiem lub jajkiem. Piec w piekarniku.

Placek z kratką - ciasto kruche: 2 żółtka, $0,5 \mathrm{~kg}$ mąki,0,5-1 szkl. śmietany, 20-25 dkg margaryny lub masła (do placka z kruszonki nie dodaje się śmietany), 1 łyżeczka proszku do pieczenia, $1 / 2$ szkl. cukru. Zagnieść ciasto, $2 / 3$ rozwałkować na blasze, wyłożyć farsz: twaróg przygotowany jak na kaszniki, dżem domowy lub owoce sezonowe. Na wierzchu ułożyć kratkę z reszty ciasta pociętego na paski szerokości około $1 \mathrm{~cm}$. Piec w piekarniku.

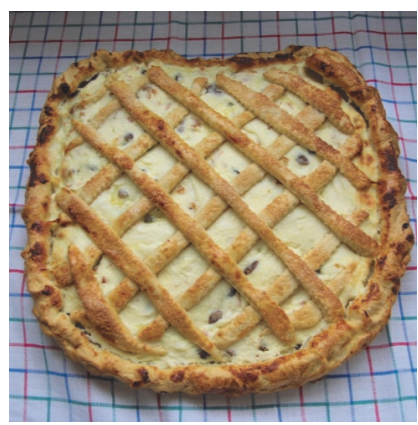

\section{Sobota}

Sobotnie potrawy przygotowywane były w piątek i pozostawiane w utrzymującym ciepło piecu chlebowym (tzw. ruskim) do sobotniego obiadu lub kolacji. Szczególnym przysmakiem było mleko prażone - pozostawione na całą noc w piecu nabierało kremowego koloru i pokryte było brązowawą skórką, która stanowiła dziecięcy sobotni smakołyk.

Biok - babka kartoflana wysoka pieczona w kamionkowej formie.

Gannawy (z języka hebrajskiego 'złodzieje', opowieść głosi, że potrawa była tak smaczna, że złodzieje włazili przez komin i wykradali ją z garnka) - kule (podobne do tzw. cepelinów) uformowane z surowych ziemniaków, utartych i dobrze odciśniętych przez płócienną ściereczkę, ewentualnie z dodatkiem drobno pokrojonego mięsa (lub nadziewane farszem z mięsa), duszone, gotowane razem z kaszą perłówką albo krojoną marchewką (zwane również cimiś). Wody dodaje się jak do każdej zupy, w trakcie gotowania potrawa gęstnieje.

Szwilpiki - pierożki z ciasta z rozgniecionych ugotowanych ziemniaków $\mathrm{z}$ dodatkiem 1 jajka i soli, z farszem z duszonej kapusty z cebulą i olejem. Uformowane na kształt kybyna układa się na liściach kapusty i piecze w piekarniku. Jeść można je było od razu, lecz na ogół ułożone w brytfance pod przykryciem i wstawione do ruskiego pieca, oczekiwały w cieple na sobotni obiad. Dziś często podaje się je na drugi dzień - odgrzewane są równie smaczne, serwowane $\mathrm{z}$ surówką lub sosem grzybowym.

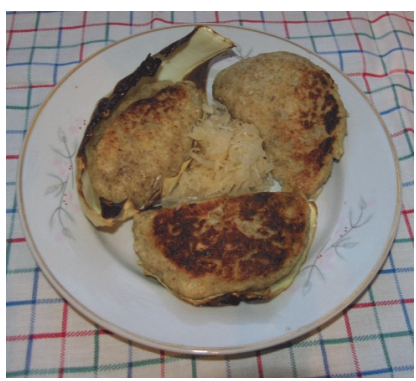


Kubitień - placek ze słonego ciasta drożdżowego z farszem. Farsz mógł być rozmaity: z mięsa, kapusty i cebuli (tak sam jak farsz do kybynów), mięsa, ryżu i cebuli (mięso najczęściej baranie krojone w kosteczkę jak do kybynów). Zamiast krojonego mięsa mógł być też podzielony na części kurczak, ułożony na warstwie poszatkowanej kapusty lub kartofli. Inny rodzaj farszu to mielone gotowane płucka $\mathrm{z}$ gotowanym mięsem i poszatkowaną cebulą. Prawdziwym specjałem był kubitień z... głową baranią pokrojoną na duże kawałki ułożoną

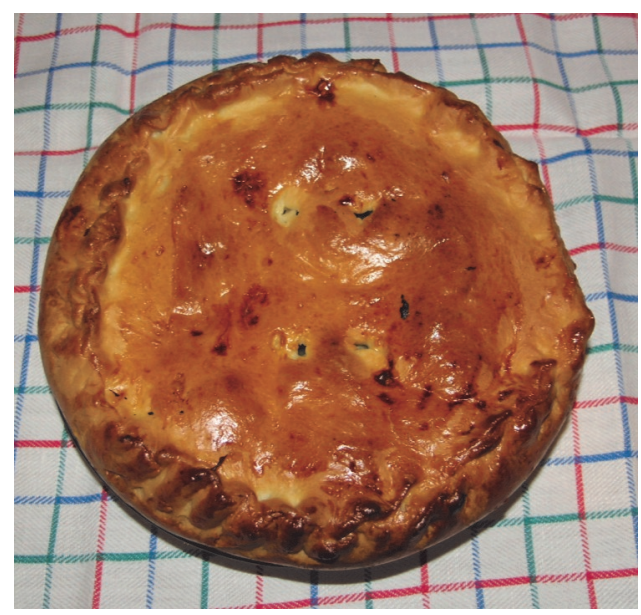
na warstwie poszatkowanej kapusty.

Z ciasta uformować płat, wyłożyć nim posmarowaną tłuszczem blachę do pieczenia. Ułożyć farsz i przykryć drugim płatem ciasta drożdżowego. Brzegi skleić i zawinąć. Wierzch podziurkować widelcem, posmarować rozmąconym, lekko osolonym żółtkiem lub jajkiem. Piec w piekarniku na złoty kolor.

\section{Chydży tymbyłłarnyn}

Przygotowanie do tego święta wymagało kilkutygodniowej wytężonej pracy. Należało dokładnie posprzątać cały dom i usunąć zeń wszelkie niezgodne $\mathrm{z}$ biblijnymi nakazami potrawy. Pozbywano się wszystkiego, co „kwaśne”, najczęściej wynosząc po prostu produkty do oddzielnej komórki. Bielono miedziane garnki, a w niektórych domach wręcz wymieniano zestaw garnków i naczyń na specjalny, świąteczny. Przygotowanie

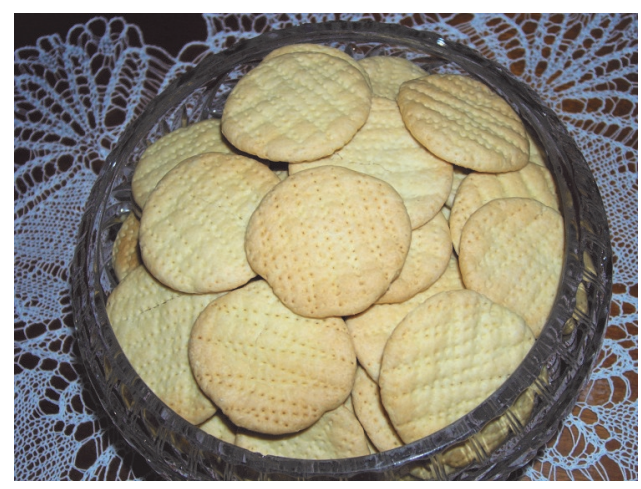
tymbyłów (przaśników) w ilości wystarczającej dla całej rodziny przez cały świąteczny tydzień stanowiło duże wyzwanie, dlatego wykonanie go nierzadko zlecano wyspecjalizowanym gospodyniom. Każda gospodyni przepisy na tradycyjne dania modyfikowała zgodnie ze swym gustem i smakiem i nigdy ta sama potrawa próbowana w dwóch domach nie smakowała tak samo.

Podstawą menu świątecznej kolacji są:

Tymbyły, które je się przez tydzień zamiast wypiekanego na drożdżach czy zakwasie chleba. Przaśniki są również podstawą przygotowania wielu świątecznych potraw. 
Tymbyły cienkie - wyrabiane z wody i mąki;

Tymbyły grube - wyrabiane z $1 \mathrm{~kg}$ mąki, $250 \mathrm{~g}$ masła, 1 żółtko, 0,5 l. śmietanki (18-36\%) lub mleka (proporcje według uznania gospodyni - jeśli więcej tłuszczu to mniej mleka). Wszystkie składniki łączy się od razu, nie wolno składników uzupełniać, podsypywać ani podlewać.

Jajka pieczone - w piekarniku, na blaszce

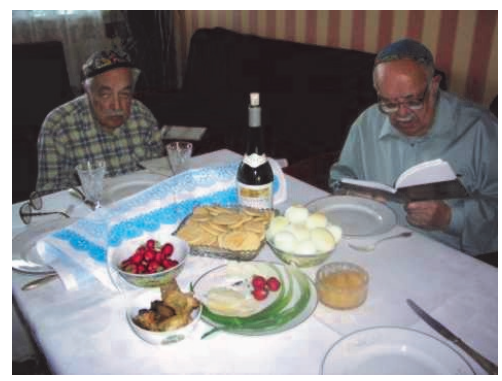
pod solą.

\section{Pieczeń z baraniny.}

Gorzkie zioła - chrzan, szczypiorek, rzodkiewki.

Sohanczeh - pasztet z rozgniecionych pieczonych jajek, drobno siekanej cebuli i masła.

Wypieki z mąki tymbyłowej. Cienkie tymbyły po upieczeniu mieli się w ręcznym młynku, następnie dzieli w zależności od grubości przemiału na dwa rodzaje - drobną mąkę do biszkoptu, grubą do gałek, babek, kubitienia i pierogów. Całych cienkich tymbyłów używa się do zapiekanek.

Proporcje stosowane do przygotowania ciasta $\mathrm{z}$ mąki tymbyłowej ustalane są zawsze indywidualnie, im bardziej sucha mąka, tym więcej wymaga płynu. Należy jednak pamiętać, że łatwiej jest dodać mąkę do przygotowywanego ciasta, jeśli zachodzi taka potrzeba, podsypując po trochę niż rozmiękczyć zbyt twarde ciasto.

Przykładowe proporcje:

2 szklanki mąki, około 0,5 litra wody lub mleka, 1-2 jajka, szczypta soli. Rozmieszane składniki pozostawić na około 0,5 - 1 godzinę aby się połączyły. Jeżeli trzeba dodać po trochę mąki.

Kubitien z ciasta tymbyłowego (przepis babci Zosi Zarkowej):

Ciasto: 1-2 szkl. mąki tymbyłowej, jajko, tłuszcz gęsi, masło, woda. Wyrobić ciasto miękkie nie do wałkowania. Farsz: 20-30 dkg surowe chude mięso krojone w kostkę, 5 dkg tłuszczu (jeśli mięso jest przerośnięte to nie dodajemy tłuszczu), 1-2 łyżki wody, 1 cebula, przyprawy.

Wyłożyć pierwszą warstwę ciasta do nasmarowanej tłuszczem formy, następnie wyłożyć farsz, a na koniec drugą warstwę ciasta. Piec w piekarniku.

Do ulubionych dań świątecznych należą gałki ze śliwkami i z mięsem:

Wyrobić dość luźne ciasto z mąki tymbyłowej, jajka, tłuszczu (np. gęsiego), masła, wody. W zwilżonej dłoni albo na desce posypanej cienką mąką tymbyłową rozłożyć ciasto, ułożyć farsz (mielone gotowane mięso lub suszone śliwki - dodaje się orzeszek masła do środka), formować

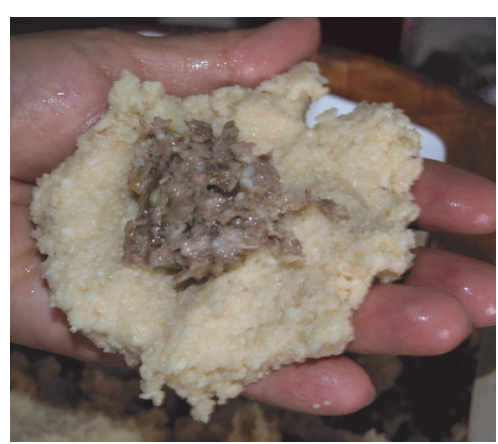

Proces robienia gałek - ciasto tymbyłowe z farszem 
gałki okrągłe lub owalne. Gałki mogą być również bez farszu, przygotowane jako dodatek do pieczonego mięsa.

Inne dania to:

pierożki z mięsem $\mathrm{z}$ gęstszego ciasta, do wałkowania, $\mathrm{z}$ nadzieniem z mielonego gotowanego mięsa. Po upieczeniu w piekarniku przekłada się je do brytfanki posmarowanej tłuszczem. podlewa rosołem i zapieka w piecu pod przykryciem;

zapiekanka z cienkich tymbyłów połamanych i namoczonych $\mathrm{w}$ mleku, z farszem z suszonych śliwek na słodko bądź z cebuli i pieczarek na pikantnie;

tort tymbyłowy na biszkopcie z 6 łyżek cienkiej mąki tybyłowej, 6 jaj, 6 łyżek cukru, 6 łyżek wody. Sposób przygotowania: ubić pianę z białek, do sztywnej piany dodawać stopniowo cukier, żółtka z wodą, na koniec delikatnie połączyć z mąką. Piec w tortownicy. Gotowy biszkopt przekładać kremem maślanym.

Z okazji innych świat też podawano charakterystyczne potrawy:

Jarty san - 25 dni po Chydży tymbyłłarnyn licząc od niedzieli

Jajka malowane - gotowane w łupinach cebuli

Wspomniane już wcześniej kaszniki.

\section{Chydży aftałarnyn}

Katłama - wypiek złożony z siedmiu warstw: czterech z ciasta drożdżowego i trzech warstw słodkiego farszu $\mathrm{z}$ twarogu z rodzynkami.

Zapiekane serniki - pierogi z białym serem, obgotowane i zapieczone $\mathrm{w}$ formie pod śmietaną.

Kaszniki.

Byrhy kiuniu

Okrągłe bułki drożdżowe - z ząbkami dookoła i różyczką na wierzchu.

Babka drożdżowa słodka $\mathrm{z}$ rodzynkami - okrągła, żeby okrągły był cały rok (okrągły kształt był dobrą wróżbą).

Zupa - rosół z kury ze szczypanką.

\section{Boszatłych}

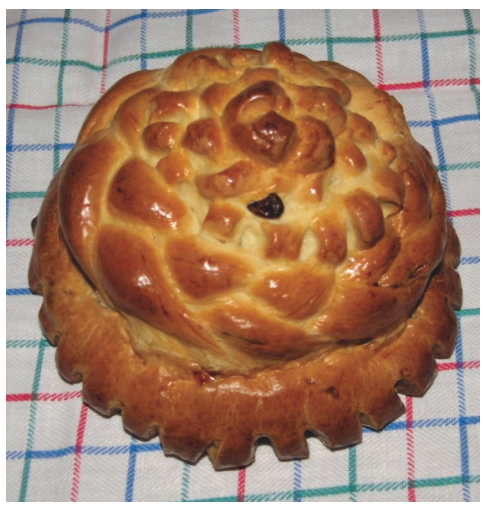

W przeddzień święta wypiekano specjalną bułkę drożdżową o charakterystycznym kształcie: trzy wałki okrągłe połączone poprzecznie warkoczykami. Miała ona symbolizować drabinę do nieba.

\section{Chydży ałaczychłarnyn}

Owoce 


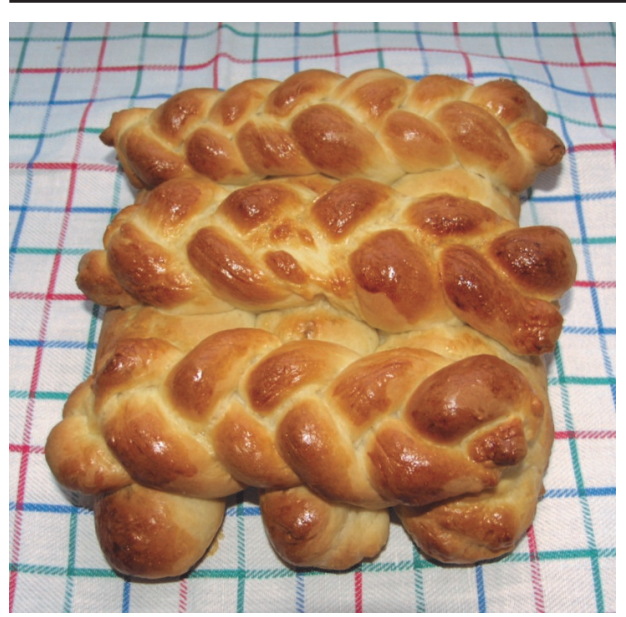

Drabina do nieba

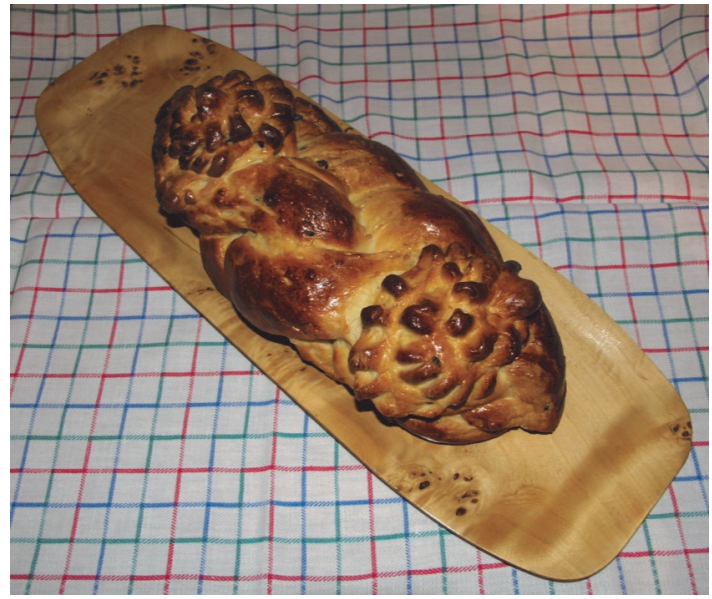

Łoduszka

Łoduszka - podłużna bułka drożdżowa pleciona, z różyczkami na końcach. Nad bułka odmawiano modlitwę, po czym dzielono ja pomiędzy wszystkich obecnych.

\section{Kynysz}

Kynysze - trójkątne bułki z ciasta drożdżowego, z farszem z maku (przygotowanego jak do makowca), z mielonych śliwek suszonych, rodzynek, orzechów. Dawniej suchy mak miażdżono w stępie (dużym drewnianym moździerzu), następnie zagotowywano z cukrem i wodą (na pół kilo maku szklanka wody i pół szklanki cukru), gdy wystygł, dodawano porcjami do ubitej na sztywno piany z dwóch białek.

\section{Uroczystości rodzinne Pogrzeb i okres żałoby}

Podawano wtedy potrawy postne, np. kybyny robiono nie z mięsem, lecz $\mathrm{z}$ rybą czy kapustą. Przygotowywano pierożki $\mathrm{z}$ ciasta drożdżowego, z farszem z podduszoną kapustą z cebulą bądź z kapustą i gotowanym jajkiem i koperkiem, kapustą i pieczarkami lub suszonymi grzybami lub ze śledziem i ryżem. Również słodycze występowały w specjalnej, „żałobnej” wersji, jak na przykład czarna chałwa.
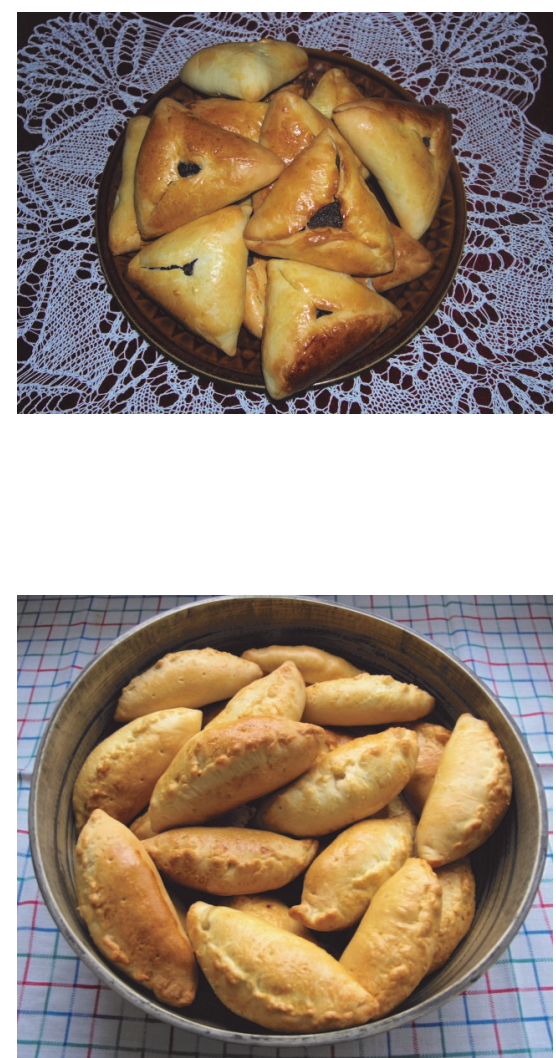


\section{Chałwa czarna}

Składniki: 1 kg mąki, 0,5 kg miodu, 0,5 cukru, 20-25 szt. ziaren goździków lub pieprzu, 1 szklanka wody. Mąkę przesiać i uprażyć na suchej patelni aż nabierze ciemnobrązowego koloru. Wystudzić i odsiać grudki spalonej maki. Miód połączyć z cukrem, mieszając, dodać szklankę wody, a następnie gotować na małym ogniu 10-12 min., aż powstanie gęstawy syrop. Odstawić do przestygnięcia. Mąkę połączyć z mielonym pieprzem lub goździkami (im młodszy był zmarły, tym bardziej piekąca powinna być chałwa), zalać ciepłym syropem, stale mieszając, aż powstanie gęste ciasto. Podzielić je na 2-3 części, uderzać nimi w stołową deskę aż staną się gładkie i błyszczące. Ciepłe ciasto rozwałkować na grubość 1-1,5 cm., pokroić na kawałki, rozłożyć na talerzu posmarowanym masłem. Odstawić do stwardnienia na 2-3 godz.

Często spotykanym składnikiem dań postnych i żałobnych były ryby. Spożywano je jednak nie tylko przy okazji smutnych wydarzeń. Niewątpliwie okolicznością sprzyjającą obecności ryb w karaimskim menu była bliskość jezior i rzek (ulice karaimskie biegły $\mathrm{w}$ pobliżu wody - w Trokach między jeziorami, w Łucku nad rzeką Styr, w Haliczu - nad Dniestrem). W Trokach chętnie gotowano różnego rodzaju zupy rybne. Podstawą ich były drobne ryby oczyszczone z głów, ogonków, kiszek i łusek. Ryb pozbawionych łusek (np. węgorzy) nie jadano. Czysty, odcedzony bulion rybny $\mathrm{z}$ gotowanymi $\mathrm{w}$ nim warzywami (marchewką, pietruszką, cebulą czy selerem) był podawany do popijania pieczonych pierożków z farszem jarzynowym, grzybowym czy jajecznym. Przygotowywano także zupę rybną z klopsikami kofta z rybiego mięsa (na Chyży Tymbyłłarnyn do klopsików dodawano nie zwykła mąkę, lecz tymbyłową), szczupaka faszerowanego w galarecie, lina gotowanego w mleku lub śmietanie. Z drobnych ryb przyrządzano zapiekankę, układając je warstwami na przemian z pokrojonymi w plastry ziemniakami i cebulą i zalewając rozbełtanymi jajkami, śmietaną lub olejem. Z farszem rybnym przygotowywano także kubietień.

\section{Ślub i wesele}

Reszetka, czyli okrągła bułka ze słodkiego drożdżowego ciasta, zdobiona różami i pięcioma warkoczami z ciasta, przygotowywana przez kobiety z rodziny pana młodego, jest niezbędnym rekwizytem podczas kieleszmiaku, obrzędu zaręczyn. Na niej właśnie wnoszony jest welon młodej, a pod welonem umieszczone są jeszcze cukierki, rodzynki, orzechy - prezent od pana młodego dla narzeczonej. Przygotowuje się także:

Tirki - mniejszą okrągłą bułkę ozdobiona trzema podłużnymi warkoczami, różą na czubku i warkoczem dookoła,

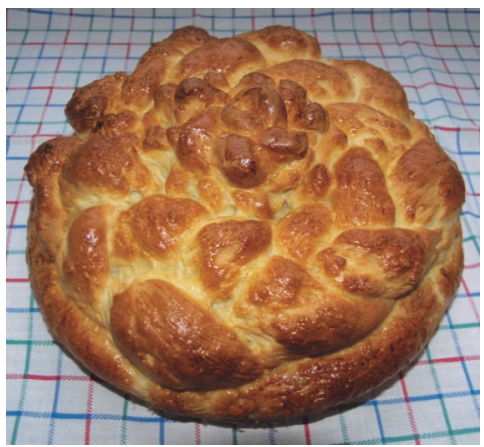

Bułka Tirki

Łoduszka - podłużne, plecione bułki drożdżowe również zdobione na końcach różyczkami (tirkiczeklar), przygotowywane przez kobiety z rodziny panny młodej. 


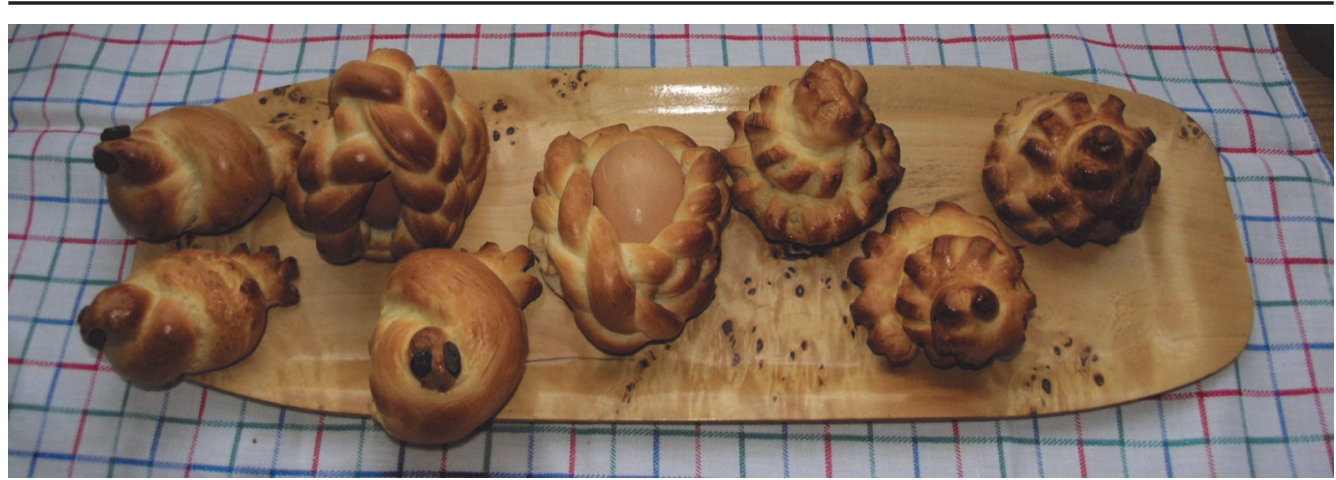

Bułkami częstuje się zgromadzonych podczas tej uroczystości gości po uroczystej ceremonii założenia welonu na głowę panny młodej. Specjalnie dla najmłodszych piecze się słodkie różyczki dla dziewcząt i koguciki dla chłopców.

Młodzi w dzień ślubu poszczą od rana, a pierwszym posiłkiem, jaki podaje się im podczas wesela, są kurze udka. Weselnych gości częstuje się rosołem. Dawniej obyczaj nakazywał mieć ze sobą łyżkę, którą każdy trzymał w cholewie.

\section{Narodziny}

Z tej okazji piecze się słodką bułkę drożdżową w formie wianka, a także z ciasta drożdżowego różyczki dla dziewczynek i koguciki dla chłopców.

\section{Napitki}

Krupnik

1/2 l wódki (jeżeli spirytus - 1/4 l rozcieńczyć pół na pół z wodą), 1/2 szklanki cukru, 1 orzech muszkatołowy pokrojony, 3 goździki, kawałek cynamonu, 1/2 łyżeczki herbaty liściastej. Składniki wymieszać, zagotować, ostudzić, przecedzić.

\section{Krupnik według przepisu Kostka}

1/2 litra spirytusu, 1/2 litra wody (niskozmineralizowanej, np. Bonaqua), 5-7 cm laski cynamonu, 7-8 goździków, 1 średnia gałka muszkatołowa (lekko rozdrobniona), 1 niepełna łyżeczka herbaty (w listkach), kawałeczek suszonej skórki pomarańczowej, 3 pełne stołowe łyżki cukru.

Przyprawy obwiązać dokładnie gazą i gotować w osłodzonej wodzie przez 3 minuty na wolnym ogniu, pod przykryciem. Odstawić do przestygnięcia na 15-20 min. Wlać spirytus i podgrzewać, na bardzo wolnym ogniu, aż osiągnie punkt wrzenia (wszystko pod przykryciem, najlepiej pod szklaną przykrywka, by nie przegapić momentu wrzenia). Owinąć szczelnie foliowym workiem i zostawić w piernatach na noc, niech bardzo wolno stygnie. Rano usunąć zawiniątko z przyprawami i rozlać trunek do butelek. Zakorkować.

\section{Kwas z suszonych owoców}

Jabłka i gruszki (dziczki) zalać wrzącą wodą. Odstawić na kilka dni, by napój sfermentował. 
Bardzo ważną pozycje w karaimskim jadłospisie stanowiły przetwory - w czasach, gdy praktycznie nie znano upraw szklarniowych, nie sprowadzano warzyw i owoców z południowej półkuli, zimą i na przednówku to one właśnie były źródłem niezbędnych witamin. Przygotowanie przetworów z owoców, jagód, grzybów, ogórków, kapusty troccy Karaimi zaczynali już wczesnym latem. Kobiety z dziećmi pokonując nieraz kilka kilometrów wybierały się do lasu na jagody, poziomki, maliny. Na mokradłach zbierano żurawiny. Mniejsze dzieci jeśli nawet nie pomagały w zbieraniu, to przynajmniej najadły się do syta, a czasem coś też do kosza wrzuciły. W domu te bogactwa gotowano lub suszono. Jesienią nadchodził czas na grzyby. Suszono je i solono. Nadzwyczaj smaczne były solone rydze. Wpierw zagotowywano je w lekko osolonej wodzie, następnie układano w glinianym dzbanie, przesypując solą. Zimą do opłukanych i pokrojonych grzybów wystarczyło dodać cebulę i gotowane ziemniaki, a powstawało smaczne i pożywne obiadowe danie.

Każda gospodyni miała swoje pomysły jak urozmaicić zimowe menu i zdrowo żywić rodzinę. W każdym domu były przygotowane beczki z kiszonymi ogórkami i kapustą. Szatkowanie kapusty wymagało dużo wysiłku, dlatego sąsiadki przychodziły z pomocą jedna drugiej. Męska pomoc była niezbędna przy ubijaniu w beczce poszatkowanej kapusty, przekładanej kminkiem, żurawinami, tartą marchewką i solą. Nieraz na dół beczki wrzucano całe głowy kapusty, albo też stopniowo dorzucano całe jabłka. Takie kiszone głowy kapusty przydawały się do robienia gołąbków wiosną, kiedy świeżej kapusty już nie było. Po kilku dniach nakłuwania, gdy zawartość się ukisiła, wynoszono beczki do chłodnych sieni. Lnianą ściereczkę, którą nakrywano kapustę, należało regularnie płukać. Kapusta i ogórki z beczki wystarczały do wiosny. Jabłka kiszone chętnie zjadano na deser. Zimą nie było w tamtych czasach żadnych świeżych owoców, jarzyn ani nowalijek. Ważnym elementem diety były więc różnego rodzaju zioła, które zbierano latem i jesienią. Zbieranie ich często powierzano dzieciom, dla których była to wspaniała zabawa, ale i też powód do dumy z wykonanego obowiązku. Jako lek na przeziębienie stosowano herbatę z lipowych kwiatów i napar z gałązek malin. Napój jarzębinowy z jarzębiny zbieranej po pierwszych przymrozkach z niewielkim dodatkiem cukru był codziennie na stole - owoce zalewało się wrzątkiem kilkakrotnie. Herbata $\mathrm{z}$ suszonych gałązek z owocami poziomek bardzo smakowała wieczorem, szczególnie po powrocie z łaźni.

Tradycyjną karaimską kuchnię z Trok wzbogacały również przepisy z Krymu. Po II wojnie światowej ponownie nawiązano kontakty z rodakami, którzy nie wróciwszy z ewakuacji w 1915 roku, pozostali na Krymie. Pamiętam naszą pierwszą podróż w 1959 roku na Krym do Eupatorii, gdzie mieszkali kuzyni ojca: Ilja i Siemion Juchniewicze. To były niezapomniane chwile. Poznałyśmy wtedy obie z siostrą członków kilku zamieszkujących tam rodzin: Mangubich, Szpakowskich, Kalfa, Miczrich i innych. Częstowano nas karaimskimi przysmakami z produktów u nas wówczas nie znanych, takich jak ryba kiefal, bakłażany, papryka, słodka fioletowa cebula. Po raz pierwszy spróbowałyśmy melonów 
i oliwek. Stopniowo dania z tych składników zaczęły wchodzić do naszej kuchni. Ale jeszcze przed II wojną popularny był w Trokach inny krymski specjał - biała chałwa, której recepturę przywiozła z Krymu Channasara Rojecka i trzymała ją w tajemnicy. Moja mama, która pomagała jej przy wyrobie tego smakołyku, marzyła, by kiedyś poznać ten sekret. Tę chałwę chłopcy sprzedawali później na brzegu jeziora turystom, pomagając $\mathrm{w}$ ten sposób podreperować skromne domowe budżety.

\section{Ak kałwa - biała chałwa, ulubiony słodki świąteczny poczęstunek.}

Przepis Aleksandry ze Szpakowskich Mangubi:

$1,5 \mathrm{~kg}$ cukru, 12 białek, 1 łyżeczka kwasku cytrynowego, cukier waniliowy, 60-70 dkg łuskanych laskowych orzechów.

W idealnie czystym aluminiowym garnku zalać cukier niewielką ilością wody, tak aby cały był mokry. Doprowadzić do wrzenia i gotować 5-6 minut, uważając, by się nie przypalił. W tym czasie rozpuścić kwasek cytrynowy, rozprowadzając go w stołowej gorącej łyżce wody. Wlać do cukru i dokładnie zamieszać. Syrop gotować dalej, uważając, by nie zżółkł. Gotować do momentu, kiedy wystygnięty syrop schłodzony będzie się ciągnął. Zdjąć z gazu, przelać do emaliowanej miski i lekko ostudzić, mieszając drewnianą łyżką. Białka ubić na sztywną pianę. Dodawać ją partiami do syropu, nie przestając szybko mieszać. Syrop musi być lekko ciepły, inaczej nie połączy się z białkami. Miskę z syropem wymieszanym z piana postawić na niewielkim ogniu, wystarczającym, by zawartość była stale podgrzewana, a jednocześnie nie brązowiała. Tradycyjnie ustawia się miskę na odwróconym taborecie nad grzałką, ustalając odległość metodą prób i błędów, by wybierać najbardziej optymalną. Masę nieustająco mieszać drewnianą łopatką przez 2-3 godziny. Chałwa powinna być biała i łamać się po wystudzeniu. Aby sprawdzić, czy chałwa ma właściwą konsystencję, trzeba odrobinę chałwy na czubku noża włożyć na chwilę do lodówki - jeśli można ją skruszyć, jest dobra. Do gotowej chałwy wrzucić uprzednio uprażone na patelni lub w piekarniku orzechy. Chałową masę nabierać łopatką i układać na posypanej cukrem pudrem tacy lub półmisku. Wybrać całą chałwę z misy i podzielić na placki lub cukierki - wałkując wałeczki grubości palca, krojone następnie na walce długości około pięciu centymetrów. Każdy cukierek zawinąć w papier-pergamin. Przechowywać w szczelnie zamykanym pudełku.

\section{Wybrane dania z kuchni krymskiej \\ Pieróg z kapustą}

Ciasto: 1 kg mąki, 0,5 opakowania margaryny, woda (ile potrzeba), sól i cukier

Farsz: kapusta, jajko, masło lub margaryna, sól i pieprz.

Kapustę poszatkować, podlać odrobiną wody, poddusić, dodać margarynę lub masło wg uznania, sól, pieprz, surowe jajko. Można dodać też posiekane gotowane jajka. Farsz można też przygotować z gotowanego mięsa, koniecznie z dodatkiem surowego jajka.

Zagnieść ciasto, rozwałkować okrągły placek. Na jedną połowę wyłożyć farsz, zakryć drugą i skleić brzegi, formując duży pieróg. Posmarować rozbełtanym jajkiem, piec w piekarniku. 
Z tego samego rodzaju ciasta robi się też kuwiet' - pieróg z nadzieniem z kartofli bądź ryżu z mięsem oraz kawurhan et'ajakłyk z farszem z mielonego gotowanego mięsa, ale bez dodatku jajek. Danie zwane byrmaczych to placek $\mathrm{z}$ ciasta $\mathrm{z}$ mięsnym farszem zwinięty $\mathrm{w}$ rulon, a następnie spiralnie ułożony w okrągłej formie i upieczony w piekarniku.

\section{Imam bajyldy}

Po $1 \mathrm{~kg}$ papryki (lub bakłażanów) i pomidorów, $1 / 2 \mathrm{~kg}$ marchwi, po $1 / 2 \mathrm{~kg}$ selera korzeniowego i pietruszki, 2-3 cebule

Paprykę opiec w piekarniku, zdjąć z niej skórkę. Warzywa obrać i pokroić w słupki. Obsmażyć każdy rodzaj warzywa oddzielnie na oliwie. Następnie połączyć i dusić warzywa razem w jednym garnku, bez przykrycia, na koniec dodać sok z pomidorów, sól i cukier do smaku.

\section{Kawior z bakłażanów}

Po $1 \mathrm{~kg}$ bakłażanów i pomidorów, po $1 / 2 \mathrm{~kg}$ selera korzeniowego i pietruszki, 2-3 cebule

Wariant I

Paprykę i bakłażany opiec w piekarniku, zdjąć skórkę. Drobno posiekać lub zmielić maszynką do mięsa. Następnie połączyć, doprawić solą i pieprzem, dodać siekane oliwki.

Wariant II

Dusić warzywa oddzielnie, białe warzywa (pietruszka i seler) razem, na otwartej patelni. Następnie połączyć i dodać siekane oliwki.

\section{Kajhana}

Gotowane mięso zemleć (można dodać tłuszcz, jeśli mięso jest chude). Dodać surowe jajka, by powstała gładka masa. Białka można ubić na pianę i dodawać ją do mięsa, delikatnie mieszając. Do farszu można dodać też szpinak. Doprawić do smaku solą i pieprzem. Wyłożyć do posmarowanej masłem, ogrzanej brytfanki i zapiec w piekarniku. Podawać gorące.

\section{Kofte}

Z mielonego mięsa, takiego jak na kotlety, formować gałeczki, obtoczyć w mące i obsmażyć na patelni. Podsmażyć cebulę. Następnie cebulę i gałeczki włożyć do garnka, dodać rodzynki, suszone śliwki i dusić. Dodać łyżkę dżemu lub sok, doprawić solą i pieprzem.

Szymon Firkowicz wspominając kulinarne obyczaje trockie, napisał słowa popularnej dziś pieśni:

\section{Zapach piątku}

Jak ptak na skrzydłach

Poleciał bym do Trok,

Tęsknotę budzi

Zapach piątku.

\section{Ijisi baraskinin}

Czypczychłej uczma Trochka

Kisiańczi üriagimniń,

Ornatsa burunczochka

Ijisi baraskiniń. 
Tam na wyspę wzywa mnie zamek Witoldowy.

Gotujący się rosół z makaronem, Zapach piątku.

Na niebiosach księżyc niby kybyn kusi.

Pełnia księżyca gałkę przypomina, Czuję zapach piątku.

Wyspy są na podobieństwo

babki ziemniaczanej

Cieszą me oczy,

Przywołują zapach piątku!
Otraczta kiermiań turad,

Sarajy Watat Bijniń.

Mijyhyn tutmacz burat,

Ijisi baraskiniń.

Kioklardia jarym ajczech, Jysunu kybynczechnyn. Aj tołu - oł koptaczech, Ijisi baraskiniń.

Otraczłar - kiorkiu giol'niuń, Jubanczy kiożlarimniń.

Tiursiuniu kibik biokniuń Ijisi baraskiniń.

Opisany przez niego zaczarowany świat ze swoją tradycją, kulturą, pieśnią, kuchnią i ukochanym językiem żyje w nas, dokąd by nas los nie rzucił, zachęca do działania, do ratowania go przed zapomnieniem i zachowania dla przyszłych pokoleń.

Źródła i literatura:

1. Domowa książka kucharska Anny z Juchniewiczów Szpakowskiej.

2. Domowa książka kucharska Konstantego Pileckiego.

3. Domowa książka kucharska Ludmiły z Mangubi Juchniewicz.

4. Domowa książka kucharska Tamary z Szyszmanów Szpakowskiej.

5. Domowa książka kucharska Zofii z Juchniewiczów Abkowicz.

6. $\quad$ Firkovič L., Firkovič J., Obyčai i prazdniki Litovskih karaimov. Trakaj 1994. [maszynopis]

7. Notatka z rozmowy przeprowadzonej $\mathrm{w}$ Trokach z Zofią z Abkowiczów Firkowiczową, zwaną Zarkową. 1986 - 1987

8. Traczyk K.M., Obrzędowość i obyczaje u Karaimów. W: Karaimi. Materiałyz sesji naukowej. Pod red. A. Dubińskiego, E. Śliwki. Pieniężno 1987, s. 64-74. 